\title{
TOWARDS A STRATEGIC EPIDEMIOLOGY OF OCCUPATIONAL SAFETY AND HEALTH
}

\author{
Jose Palacio Angulo ${ }^{1 *}$, Irlena Ahumada Villafañe ${ }^{2}$, Ivan Dario Orjuela ${ }^{3}$ y Jorge Posada Lopez \\ 1,2,3 Universidad Corporación Universitaria Minuto de Dios-UNIMINUTO. Barranquilla, Colombia \\ *Autor de correspondencia: jose.palacio@uniminuto.edu.co
}

Recibido Octubre 2018; Aceptado Diciembre 2018

\begin{abstract}
A review was made on the most relevant documents on strategic epidemiology for occupational safety and health. The present article has as peculiarity to analyze qualitatively the scientific literature available in the databases Scielo, Redalyc and official Web pages, using as search words: epidemiology, industrial safety and occupational health. Relevant information was obtained related to the proposed objective, which is presented in 3 sections: the epidemiology of safety and health; concepts, measures and studies in epidemiology and present and future challenges.
\end{abstract}

Keywords: Health, risk, occupational safety, safety management systems.

\section{HACIA UNA EPIDEMIOLOGÍA ESTRATÉGICA DE SEGURIDAD Y SALUD OCUPACIONAL}

Resúmen - Se realizó una revisión de los documentos más relevantes sobre epidemiología estratégica para la seguridad y salud en el trabajo. El presente artículo tiene como particularidad analizar cualitativamente la literatura científica disponible en las bases de datos Scielo, Redalyc y páginas web oficiales, utilizando como palabras de búsqueda: epidemiología, seguridad industrial y salud ocupacional. Se obtuvo información relevante relacionada con el objetivo propuesto, que se presenta en 3 apartados: la epidemiología de la seguridad y la salud; conceptos, medidas y estudios en epidemiología y desafíos presentes y futuros.

Palabras Clave: Salud, riesgo, seguridad ocupacional, sistemas de gestión de seguridad.

\section{INTRODUCTION}

The etymological epidemiology comes from the Greek words epi (on), demos (people) and logo (study or give an account). That is, it would mean the study of what happens in the town (Clara,2009). The World Health Organization, officially defines epidemiology as the study of the distribution and determinants of states or events (in particular of diseases) related to health and the application of these studies to the control of diseases and other health problems. There are several methods to carry out epidemiological

IPSA SCIENTIA - Vol. 3 № $1-2018$ 
investigations: surveillance and descriptive studies can be used to analyze the distribution, and analytical studies allow to analyze the determining factors (Gómez \& Severiche, 2018).

Likewise, Marantz (2011) in the congress of the Argentine society's census states that epidemiology has had different definitions in modernity by different authors, such as: Barker (1993), who defines it as the study of distribution and determinants of diseases in human populations; Fox (1970) defines it as the study of the factors that determine the occurrence of the disease in populations; Kerdel (2004) and Garcia (2012) resembles a medical Ecology; De Miguel et al. (2012), express that it is the Science responsible for the study of the ecological aspects that condition the health and disease phenomena in human groups, in order to establish the causes, mechanisms and procedures tending to promote and improve health; Lowe argues that it is the study of health problems in groups of people; Mac Mahon-Pugh (1970) will say that it is the study of the distribution of the disease and the determinants of its prevalence in man; Susser (1996) argue that it is the frequency of medical events in the populations.

Rose (1988) defines it as the study of man's health in relation to his environment; Iranzo (2008), will say that it is the part of biometrics that refers to the measurement of human characteristics; Susser (1973), will define what is the study of the distributions and determinants of health states in human populations and Terris, expressed that is the study of the health of human populations.

It is also important to highlight the concept of OMS (2013). who express that epidemiology is a science whose work methodology allows the investigation of objective laws, the causes and conditions of diseases and the approach of possible solutions, both preventive and control or eradication of any health problem that affects human communities.

\section{The Epidemiology of Safety and Health}

The epidemiology of occupational safety and health is a sub-branch of epidemiology that seeks its application in the workplace, so it can be defined as the discipline that studies distribution, frequency, determinants, relationships, predictions and control of the factors related to the different health and illness events that exist in the working population.

The main objective of the epidemiology of work is the prevention, through the identification of the consequences for health, of the exhibitions in the workplace, to determine the history of the exhibitions to which a person has been subjected throughout his life work and with this information take precautions to eliminate, reduce or control the risk of workers (PAHO,2009).

Therefore, the Epidemiology of Occupational Safety and Health deals with the relationship of occurrence between work-related illnesses and the factors that determine their appearance and course (Robaina et al., 2006).

\section{History of the Epidemiology of occupational safety and health}

Occupational accidents and occupational diseases have been present since man began his existence, I do not think you can imagine the homo habilis designing tools without having an accident in its manufacture. 


\section{Towards a Strategic Epidemiology of Occupational Safety and Health}

There is also evidence of Egyptian mummies from the Manchester museum that have been performed bronchial endoscopies the frequent finding of pulmonary deposits of silica, higher than normal, which would place the silicosis, as the oldest occupational disease detected (Selva,2014).

Already in ancient Greece, Hippocrates who lived between 460 BC. and 370 BC. He wrote a treatise on the diseases of miners, detailing the symptoms of mercury and lead poisoning and suggested hygienic baths to avoid lead saturation (Arias,2012).

Approximately in 1700, Ramazzini publishes De Morbis Artificium, which was a systematic study of the diseases linked factors of the work environment, also advised that in the anamnesis of the patient should ask: What is your job?, Because of which is considered the father of occupational medicine (Donaldson \& Donaldson, 1989).

And the first study in the field of Occupational Medicine that could be labeled epidemiological was published in 1775 by Sir Percival, who called attention to the high occurrence of scrotal cancer among chimney sweeps (Roca,2013).

In 1854, John Snow, a British physician, linked contaminated water from a water pump, as a vector agent of the outbreak of cholera that occurred in London, on Broad Street; He also contributes in the calculation of infection rates and estimation of the probability of infection, merits for which he is known as the father of modern epidemiology (Andrade, 2010).

Likewise, the modern epidemiology of occupational safety and health has a history in the methods of historical cohorts of Richar Doll who published in 1950, in Great Britain, the first longitudinal epidemiological study of 20 years, detailed on textile workers- asbestos (Bedoya et al., 2018).

\section{Regulatory Framework}

Although several standards can be listed in relation to the epidemiology of occupational safety and health, which have been carried out in Colombia, it is important that this science takes legal force as of Law 1562 of 2012 and successive regulations.

Law 1562 of 2012 will establish in its article 11 numeral 2:

"Of the ninety-two percent $(92 \%)$ of the total contribution, the Occupational Risk Management Entity will allocate at least ten percent (10\%) for the following:

a) Development of regular programs for the prevention and control of occupational risks and integral rehabilitation in affiliated companies;

b) Support, advice and campaign development in its affiliated companies for the development of activities to control risks, the development of epidemiological surveillance systems and the evaluation and formulation of adjustments to the annual work plan of companies. The two main objectives of this obligation are: permanent monitoring of working and health conditions, and effective control of risk".

The numeral 36 of article 2 of decree 1443 of 2014 of the Ministry of labor, conceptualizes:

Surveillance of occupational health or epidemiological surveillance of occupational health: Includes the collection, analysis, interpretation and continuous and systematic dissemination of data for the purposes of prevention. Surveillance is essential for planning, execution and. evaluation of safety and health programs 
at work, control of work-related disorders and injuries and work absenteeism due to illness, as well as for the protection and promotion of workers' health. This surveillance includes both the monitoring of workers' health and that of the work environment.

Paragraph 1: In application of what is established in Article 10 of Law 1562 of 2012, for all purposes it will be understood as health and safety at work all that before the entry into force of this law referred to the term health occupational.

Paragraph 2: According to the previous paragraph from the date of publication of this decree will be understood. the Occupational Health Joint Committee as a Joint Committee on Occupational Health and Safety and the 'Occupational Health Vigilante as Safety and Health Vigilance in the Work, who will have the functions established in the current regulations.

Likewise, in numeral 13 of the aforementioned article of the law establishes within what the employer must keep available and duly updated, among others, the following documents in relation to the Occupational Health and Safety Management System:

Epidemiological surveillance programs for workers' health, including the results of environmental measurements and health profiles released by biological monitoring, if the latter applies according to the prioritization of risks. In the case of having medical specialist services in occupational or labor medicine, according to what is established in the current regulations, the previous and the individual results of the biological monitoring must be documented.

\section{Concepts, Measures and Studies in Epidemiology}

The endemic disease is defined as present or usually prevalent in a population or geographical area over time, it is a very old word, so much so that Galen used it in his time with the same current meaning (Agudelo, 2014), example Dengue is an endemic disease in the city of Malambo, Colombia.

The epidemic is defined as the temporary increase in the number of cases of a contagious disease above those expected for a community or population (Testa, 2011), for example the polio epidemic of 1956 in Argentina (Marrugo et al., 2017).

The labor epidemic is defined as the temporary increase in the number of cases of a contagious disease contracted as a result of exposure to risk factors inherent in the work activity or the environment in which the worker works, higher than what would be expected for a worker. a certain group of working population, a work area and a specific period of time, for example the tuberculosis epidemic of the workers of the Hospital Nacional Dos de Mayo in Lima in 2010 (Idrovo, 2000).

The pandemic is a major epidemic that spreads to several countries and more than one continent (Pinto, 2007), for example the current AIDS pandemic (Dirección General de Salud Pública, 2011).

An epidemiological conglomerate is the appearance of a number of cases of a disease in an amount greater than what would be expected for a certain population group, a specific geographical area and a certain period of time (Batista, 2013), which applies especially to non-infectious health events, and is also called an epidemiological cluster, for example: an epidemiological conglomerate of cervical cancer in Villa Clara, Cuba between 2004 and 2009 (Pérez, 2014). 
An occupational epidemiological conglomerate is the appearance of a number of cases of a noninfectious occupational disease or work accident in an amount higher than what would be expected for a certain group of working population, a work area and a certain period of time, for example the occupational epidemiological conglomerate of silicosis in workers in the quartz industry in Cádiz, Spain, between 2009 and 2012 (Moreno et al., 2000).

\section{Measures of the epidemiology of occupational safety and health}

When the researcher is going to perform epidemiological measurements, the first thing to do is to choose the measurement scale that he will use.

According to Moreno et al. (2000), the scales of measurement are classified into qualitative scales that can be nominal and ordinal and in quantitative scales that can be of intervals and of ratio.

Palencia et al. (2017), explain that qualitative scales account for the presence or absence of the categories that comprise it, when these categories do not have an implicit order among them, it is a nominal scale, example when asked by gender of the worker and the categories are male or female; when the categories present order but does not allow to quantify distance between them, it is an ordinal scale, example when the work incidents are classified into categories of mild, moderate or severe.

Sierra et al. (2014), explains that in the quantitative scales the magnitude of the distance between them can be measured, in the interval scale the distances between any pair of numbers of the scale have a known and constant dimension so it is possible to know with certainty the magnitude of the intervals, but the zero point and the unit of measure are arbitrary, for example when taking the temperature of the workplace in Celsius scale, because zero on that scale is not really absolute absence of heat; and in the scale of ratio, the distances between any pair of numbers on the scale have a known and constant dimension so that it is possible to know with certainty the magnitude of the intervals, but in this scale the zero point is true, example when measures the load of weight borne by the worker in kilograms, because the zero $\mathrm{Kg}$ really denotes the absence of weight.

Once the researcher has chosen the measurement scale, he proceeds to perform the epidemiological measurements that are classified as measures of frequency, association and potential impact (Hernández, 2000).

\section{Design of Epidemiological Studies}

Epidemiological measures are fundamental for the development of the epidemiological study to be used in the investigations that are required to be carried out in the company in reference to health and safety at work.

According to Hernandez et al. (2000), epidemiological studies can be classified according to different variables, according to the causality in experimental, pseudo-experimental or non-experimental; according to the number of measurements that the data is collected, they are longitudinal or transverse, depending on the temporality they can be retrospective or prospective; and according to the unit of analysis can be individual or ecological. 


\section{Towards a Strategic Epidemiology of Occupational Safety and Health}

The mixture of these variables between epidemiological studies defines the types of epidemiological studies that according to Burgos et al. (2018), are: ecological studies, on a case-by-case basis, case series, prevalence studies, case-control studies, cohort studies, clinical trial, field trial and community trial.

\section{Present and Future Challenges}

The strategy of the epidemiology of safety and health at work should not be reduced to give the results of epidemiological measures, only describing the current state of health of the company, but should go further, should lead to actions to decrease occupational morbidity, occupational accidents, incapacities due to work-related or occupational accidents, disability due to work-related or work-related accidents, occupational risk factors; In addition to improving the health of the worker and achieve a healthy work environment.

Therefore, the administrator of occupational safety and health should use a strategic epidemiology, the authors of this article suggest the following steps for its application, the first step called description, the second step is called analysis, the third step is called prediction, the fourth step that is called a proposal and a fifth step called implementation, which is returned to the first step, which is why the entire process has been called the DAPPI strategic pentagon of the epidemiology of occupational safety and health.

\section{References}

Agudelo Restrepo, C. A. (2014). Las epidemias en la historia de la humanidad. Revista Universitas Científica, XVII(2), 80 - 85.

Andrade, J. (2010). Definición Etimológica de Ia epidemiología. Recuperado el 19 de Febrero de 2016 , de file://C:/Users/user/Downloads/DEFINICION\%20DE\%20EPIDEMIOLOGIA\%20COMENTADAS.pdf.

Arias Gallegos, W. L. (2012). Revisión histórica de la salud ocupacional y la seguridad industrial. Revista Cubana de Salud y Trabajo, XIII(3), $45-52$.

Barker ND, Stroup NE, Lopez GM, Massey JT. Evaluation of methods employed in the assessment of health care needs and access to care in Dade County, Florida, following Hurricane Andrew. DHHS Publication No. (PHS) 94-1214. Atlanta: U.S. Department of Health and Human Services, Centers for Disease Control and Prevention; 1993.

Batista, N. (2013). Análisis espacial de la morbimortalidad del cáncer de mama y cérvix. Villa Clara. Cuba. 2004-2009. Revista Española de Salud Pública, LXXXVII(1), 49 - 57.

Bedoya-Marrugo, E. Meza-Aleman, M., Sossa-Camargo, M., Severiche, C. (2018). Analysis of Accidentality in an Industrial Sector Company between the Years 2016-2017.

Burgos-Pereira, Y., Bedoya-Marrugo, E., Vargas-Ortiz, L., Severiche, C. (2018). Chi-Square Test to Identify Factors Associated with Health Conditions in Infants of a Colombian Caribbean Root Zone. International Journal of Applied Engineering Research, 13(6), 3574-3578.

Clara, M. (2009). Epidemiología en Salud-Salud Mental. Buenos Aires, Argentina: Universidad Nacional de Lanús.

De Miguel-Bouzas, José Carlos, \& Castro-Tubío, Eva, \& Bermejo-Barrera, Ana María, \& Fernández-Gómez, Purificación, \& Estévez-Núñez, Juan Carlos, \& Tabernero-Duque, María Jesús (2012). Estudio epidemiológico de las intoxicaciones agudas atendidas en un hospital gallego entre 2005 y 2008. Adicciones, 24(3),239-246.

Dirección General de Salud Pública de Valladolid. (2011). Informe epidemiologico de investigacion del congloerado de casos de cancer infantil en el colegio Garcia Quintana de Vallodolid. Valladolid: Dirección General de Salud Pública de Valladolid. 


\section{Towards a Strategic Epidemiology of Occupational Safety and Health}

Donaldson, R. J., Donaldson, L. J. (1989). Medicina comunitaria. Madrid, España: Ediciones Díaz de Santos.

Fox JP, Hall CE, Elveback LR. Epidemiology. Man and disease. MacMillan, Nueva York, EUA, 1970.

García de Alba García, Javier E.. (2012). Saberes culturales y salud: una mirada de la realidad polifacética. Desacatos, (39), 89104.

Gómez-Bustamante, E.\& Severiche-Sierra, C. (2018). Association between Sociodemographic, Health and Work conditions in Waste pickers in Cartagena de indias (Colombian Caribbean). International Journal of ChemTech Research, 11(5), 331-341.

Hernández, M. (2000). Diseño de estudios epidemiológicos. Revista salud pública de méxico, XLII(2), 144 - 154.

Idrovo, A. (2000). Epidemias, endemias y conglomerados: conceptos básicos. Revista de la Facultad de Medicina de la Universidad Nacional, XLVIII, 175- 180.

Iranzo, Valeriano. (2008). El Dilema del realismo Experimental. EPISTEME, 28(1), 59-88.

Kerdel Vegas, Francisco. (2004). Las grandes paradojas de la medicina actual. Gaceta Médica de Caracas, $112(1)$, 15-31.

MacMahon B, Pugh TF. Epidemiology: Principles and methods. Boston: Little Brown, 1970.

Marantz, P. (2011). Epidemiología de las cardiopatías congenitas. Obtenido de Sociedad argentina de pediatria: http://www.sap.org.ar/docs/congresos/2011/centenario_sh/marantz.pdf.

Marrugo, E., Alemán, M., Giraldo, I. (2017). Accidentes laborales y enfermedades ocupacionales en Personal de odontología de Cartagena y departamento de Bolívar-Colombia. Ciencia Odontológica, 14(2), 21-26.

Moreno, A., Garcia, J., Palacios, M. (2014). Epidemiometria: medicion de la frecuencia, la fuerza de asociacion y el impacto potencial. En A. Villa, L. Moreno, \& G. Garcia, Epidemiologia y estadistica en salud publica (págs. 43 - 61). Mexico: McGRAW-HILL Interamericana editores.

Moreno, A., Lopez, S., Corcho, A. (2000). Principales medidas en epidemiología. Revista Salud Pública de México, XLII(4), $337-348$.

OMS. (2013). Epidemiología. Obtenido de Organizacion Mundial de la Salud: http://www.who.int/topics/epidemiology/es/

PAHO. (2009). Rol de la Epidemiologia en la Salud Ocupacional. Recuperado el 20 de Febrero de 2016, de Organizacion Panamericana de la Salud: http://www.bvsde.paho.org/cursoa_epi/e/modulo2.html.

Palencia, I., Bustamante, E., Severiche, C. (2017). Riegos físicos en vendedores minoristas del Mercado de Bazurto, Caribe Colombiano. Ciencia y Salud Virtual, 9(1), 13-22.

Pérez Alonso, A. (2014). Outbreak of silicosis in Spanish quartz conglomerate workers. International Journal of Occupational and Environmental Health, XX(1), 26 - 32.

Pinto, A. (2007). Compreeensao da pandemia da AIDS nos últimos 25 años. Jornal Brasileiro de Doenças Sexualmente Transmissíveis, XIX(1), $45-50$.

Rivas, G., Diaz, C. (2015). Fundamentos para la aplicación de Bioestadística en Odontología. Revista de Salud Pública de Paraguay, V(1), 33 - 39.

Robaina, C., Robaina, F., Tamargo Rodríguez, N. (2006). La epidemiología ocupacional como herramienta básica para la salud de los trabajadores. Revista Cubana de Medicina General Integral, XXII(2), 1-1.

Roca, A. J. (2013). John Snow: Desarrollos metodológicos en Epidemiología. Revista Medica, XXXV(2), 155 -167. 


\section{Towards a Strategic Epidemiology of Occupational Safety and Health}

Rose G. Individuos enfermos y poblaciones enfermas. En: Organización Panamericana de la Salud. El desafío de la Epidemiología. Washington, D.C.: OPS, 1988; (Publicación Científica núm. 505):900-909.

Selva, E. (2014). Alejandria, crisol de culturas. Recuperado el 10 de Enero de 2016, de La Página de Enrique Selva: https://sites.google.com/site/lapaginadeenriqueselvap/alejandria-crisol-de-culturas-20-10-2014/capitulo-17---medicina-ii-1medicina-egipcia.

Sierra-Calderon, D., Severiche-Sierra, C., Bedoya-Marrugo, E. (2018). Silice in the Sandblasting Industry: a review from Occupational Safety and Health. International Journal of Applied Engineering Research, 13(8), 6274-6281.

Susser M. Choosing a future of epidemiology: From black box to chinese boxes and eco-epidemiology. Am J Public Health 1996; 86(5): 674-677.

Susser, M. Causal thinking in the health sciences. Nueva York, Oxford University Press, 1973.

Testa, D. (2011). Poliomielitis: la "herencia maldita" y la esperanza de la rehabilitación. La epidemia de 1956 en la Ciudad de Buenos Aires. Intersticios, Revista sociológica de pensamiento crítico, V(2), 309 - 323. 